\title{
An Analysis of Musical Teachers Abilities in Implementing the Authentic Assessment at SMK 7 Padang Indonesia
}

\author{
Irwan, Syafri Anwar, Atmazaki, Agusti Efi
}

\begin{abstract}
This study aims to analyze the ability of music teachers in the authentic assessment at SMK 7 Padang. The methodology used in this research was descriptive by conducting interviews and giving questionnaires to music art teachers who became the sample of this study were 10 teachers. Data were analyzed with qualitative and analysis of questionnaire data with percentage values. The results showed that the ability of teachers in preparing the authentic assessment was $69 \%$, the implementation of the authentic assessment was $62.50 \%$, and feedback was $50 \%$. Accordingly, it can be concluded that the teacher has not fully carried out the authentic assessment major principles. Sadly, it was found that there were teachers who carried out the assessments based on their impulsive feeling (intuition).
\end{abstract}

Keywords: teacher's ability; music; authentic assessment

\section{INTRODUCTION}

Carrying out assessment or assessing is one of the activities that cannot be separated by the music arts teacher in the learning process in accordance with educational objectives. Article 1 of the 2003 National Education System Law states that education aims to create an atmosphere of learning and learning process so that students actively develop their potential to have spiritual strength, selfcontrol, personality, intelligence, morals, nobility, and the skills needed by themselves, the community, nation and state. In this connection to measure the achievement of the educational objectives is to carry out the assessment.

The results of the assessment can be a benchmark for teachers to assess whether the learning objectives have been achieved or not. Assessment is one of the important learning components that must be considered by educators as assessment or assessment. The new study of learning has implications for monitoring and assessment of student learning (Webb \& Romberg, 1992). Assessment can measure the construct models of individual students during the learning process (Masters \& Mislevy, 1992; Wilson, 1991). Jacob (2018: 2) explains the benefits of assessment as follows: (1) a framework for describing and reporting student performance levels, (2) a meaning of gathering information based on observational practices that are consistent with the educational variables measured and the context in which

Revised Manuscript Received on November 10, 2020.

* Correspondence Author

Irwan*, Postgraduate of Padang State University, Indonesia

Syafri Anwar, Science Educational Faculty, Padang State University, Indonesia

Atmazaki, Language and Arts Faculty, Padang State University, Indonesia

Agusti Efi, Tourism and Hospitality Faculty, Padang State University, Indonesia

(C) The Authors. Published by Blue Eyes Intelligence Engineering and Sciences Publication (BEIESP). This is an open access article under the CC BY-NC-ND license (http://creativecommons.org/licenses/by-nc-nd/4.0/)
The measurements are taking place, and (3) a measurement model that determines for the right form of quality control.

Furthermore, Purwanti (2012) explains the assessment is an integral part of the learning process, so the objectives of the assessment must be in line with the learning objectives; as an effort to gather various information with various techniques; as a material consideration in determining the level of success of the process and learning outcomes; therefore the assessment should be carried out with careful planning. The assessment must be based on the learning objectives as a whole and have certainty of success criteria, both the criteria of the success of the learning process carried out by students, or the success criteria of teaching activities carried out by educators, as well as the success of the overall learning program. Empirical studies that have been carried out in various countries relating to assessments include Karumpa, Parawangsa, Mansyur, Shaleh (2016), Wolf and Stevens (2007) from the University of Colorado, Huang (2015) the University of China, Pireh (2014) Devry and García Universities, Piquer (2015) Barcelona University, these five countries generally stated that the development of the assessment rubric test greatly improved the quality of the questions need to be used assessment rubric. Furthermore, the results of research and observations carried out in several schools must be recognized that the process of learning the existing art of music is not entirely as expected (Yosep, 2009; Astuti, 2010; and Sinaga \& Udi, 2010). The implementation of music art learning, in general, is still dominated by the use of teacher-centred lecture and drill methods. While research that discusses authentic assessment in musical composition by Deutsch (2016) explains that authentic assessment has a significant impact on student creativity. Authentic assessment results provide an illustration that students have freedom in making and playing musical compositions. Based on preliminary observations in August 2018 which were made that the process of evaluating specific learning of music art learning has not been carried out effectively by the teacher, in this case, there are guidelines in conducting the evaluation but it is less systematic, so most music art teachers do not carry out learning evaluations in accordance with existing procedures. In carrying out the assessment of music art learning there are no specific guidelines that are used because it still uses an assessment model that is also related to other learning. Some music educators believe that music teaching and learning are very difficult, if not impossible, to assess (Jurnal Edwar, 2015).

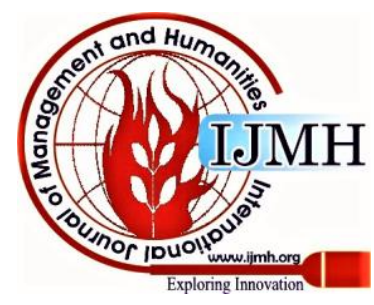




\section{An Analysis of Musical Teachers Abilities in Implementing the Authentic Assessment at SMK 7 Padang Indonesia}

Without intending to patronize or assess the music teachers, in this observation, the researcher saw that the assessment activities undertaken tended to be subjective, namely by commenting on the performance of students who were considered wrong and then for no apparent reason the teacher gave a certain value to the student's writing.

This assessment process was impressed "carelessly" atau "perfunctory." Such a method of evaluation cannot be accounted for its own objectivity.

In connection with this Zainul and Mulyana (2003: 5) "subjective assessment will cause a loss of reliability and fairness in judgment". In addition, according to the indicators of competency achievement that have been developed by the teacher in the Learning Implementation Plan (RPP), namely the demand for indicators to make writing, the assessment technique is performance and not a "scribble-off" assessment technique by giving a final score whose meaning is unclear.In fact, at present schools only pay attention to quantitative measurement aspects (numbers) and the tests made are still at the C1-C3 level, which should have been at the SMK / MA level, referring to the C4-C6 level, while the assessment aspects are qualitative (affective and psychomotor) are still ignored, and teachers have not described the levels in the affective and psychomotor domains that describe the achievement of student learning outcomes (Mulyadi, 2009). This can lead to teachers making the wrong decision as stated by Sumardi (2011) that one of the basic principles that must be constantly considered and monitored in the framework of evaluating learning outcomes is the principle of unanimity, with the evaluator's principle in carrying out an assessment of learning outcomes required to evaluate thoroughly towards students, both in terms of their understanding of the material or learning material that has been given (cognitive aspects), and in terms of appreciation (affective aspects), and their practice (psychomotor aspects).

\section{METHODOLOGIES}

The research approach used was a qualitative research approach with descriptive research type. A further qualitative approach that emphasized process compared to final results (Afifudin, 2012). This approach was used because it could reveal problems about the analysis of the abilities of music teachers in implementing the authentic assessment at SMK 7 Padang.

The selection of informants in this study was carried out using a purposive sampling technique. This meant that researchers set certain criteria that must be met by people who are used as sources of information. The criterion must be the validity of the data to be collected. (Afrizal, 2008). The research informants numbered 10 music art teachers at SMK 7 Padang.

Data analysis was performed by data collection, data reduction, data presentation and drawing conclusions or verification. This research was conducted at SMK 7 Padang. The reason researchers chose this location, because of the ease in collecting the desired research data.

\section{RESULTS ANALISYS}

From the instruments given to the research subjects, the results of research on the ability to make the 2013 Curriculum assessment tools for music art teachers at SMK 7 Padang with the number of 10 teachers in the 2018/2019 school year amounted to 10 people, with a theoretical score range of 0 - 40. The obtained empirical score data with a minimum score of 1 , a maximum score of 40 with a range of scores of 17 , and the mean score (mean) were 28.43. This score data is converted to a standard value of 100 . The description of the data is presented in Table 1 below :

Table 1. Authentic Assessment

\begin{tabular}{|l|l|c|l|}
\hline No & Indicators & Score & $\%$ \\
\hline 1 & Preparation & 18 & $69 \%$ \\
\hline 2 & Implementation & 5 & $62,5 \%$ \\
\hline 3 & Feedback & 4 & $50 \%$ \\
\hline
\end{tabular}

The results of the initial evaluation related to the existence and use of authentic assessment instruments at SMK 7 Padang for the musical arts department showed results in both categories. But not all teachers can understand, prepare authentic assessment instruments in music learning. This can be seen from the achievements of the questionnaire results given to 10 teachers who have been sampled, 4 teachers did not prepare an authentic assessment instrument or assessment instrument. More teachers who do not prepare this authentic assessment instrument tend to carry out assessments based on instinct or feeling. Learning. The results are reflected in the acquisition of the questionnaire score with a range of 50 - 69. Thus it can be concluded that $31 \%$ of teachers have not been fully able to carry out authentic assessments as they should. The results are as follows.

\section{The early (basic) abilities of the music teacher}

The teacher's initial ability to create and develop authentic assessment instruments is not maximal. The teacher does more learning administration activities such as syllabus development and learning implementation activities. Besides that, the teacher carries out more assessments based on instinct or feeling alone (this is in accordance with the results of the interview with the teacher A). This is often done by teachers until today. The assessment process is not complicated and immediately scores quickly.

Other problems in MGMP teacher activities are actually given direction to make and carry out authentic assessments. But not all teachers do it. This is due to problems of time availability, or the teacher uses an existing assessment format, without developing it again as needed. This indirectly impacts the quality of learning. Learning should be carried out to improve the learning process that is aligned with the learning objectives.

\section{Factors Causing the Teachers' Problems in} Implementing Authentic Assessments

Many factors cause teacher problems in carrying out the authentic assessment. Where these factors are often done by teachers, the availability of facilities and infrastructure. These factors present problems in authentic assessment. Teachers feel less able to develop authentic assessments that are specific to the subjects taught. The teacher found it difficult to develop items that fit the assessment indicators in each subject. To achieve this the teacher should make items that are directly related to subjects such as Band subjects. The points of the assessment instrument should be adjusted to the band so that the assessment becomes more specific.

Published By:

Blue Eyes Intelligence Engineering

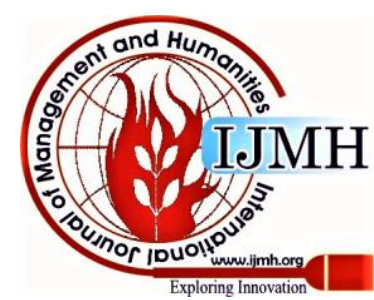


In addition, the lack of opportunities given to teachers in participating in training or developing appropriate instruments becomes an obstacle for teachers in developing these instruments. In this connection, direction from the school is needed to involve or send teachers in a variety of special training to develop an appropriate assessment instrument.

\section{CONCLUSION}

The result of this study indicates that the implementation of the authentic assessment conducted by teachers in learning music art at SMK 7 Padang has not been running as it should be expected. The teacher tends to carry out assessments based on his own institution or based on feeling alone. Assessments like these are not in line with educational goals and have a negative impact on educational goals.

\section{ACKNOWLEDGMENT}

I would like to thank our promotor Prof. Dr. Agusti Efi, Prof. Dr. Atazaki,. Prof. Dr. Syafri Anwar for their continued support, guidance, and motivation.

\section{REFERENCES}

1. Aco Karumpa, Paturungi Parawangsa, Mansyur Mansyur, Muhammad Saleh. 2016. The Development of Integrative Assessment Model for the Subject of Bahasa Indonesia in Senior High School Students. http://www.academypublication.com/ojs/index.php/jltr/article.

2. Afifuddin, Beni Ahmad Saebani. 2012. Metodologi Penelitian Kualitatif. Bandung: CV. Pustaka Setia.ic.

3. Afrizal. 2008. Metode Penelitian Kualitatif. Yogyakarta: Rajawali Press.

4. Budiningsih. 2005. Belajar Dan Mengajar. Jakarta: Rineka Cipta.

5. Dediknas. 2003. UU No 2003 Tentang Sistem Pendidikan Nasional. Jakarta: Depdiknas.

6. Herdiansyah, Haris. 2011. Metodologi Penelitian Kualitatif untuk Ilmu-Ilmu Sosial. Jakarta: Salemba Humanika.

7. Huang $\mathrm{H}$, et al. (2015). Assessment of precipitation climatology in an ensemble of CORDEX-East Asia regional climate simulations. https://www.int-res.com/abstracts/cr/v64/n2/p141-158/.

8. Kenneth Wolf, and Ellen Stevens. The Role of Rubrics in Advancing and Assessing Student Learning.

9. The Journal of Effective Teaching, Vol. 7, No.1, 2007314. https://files.eric.ed.gov/fulltext/EJ1055646.pdf.

10. Miles, dan Huberman. 1992. Analisis Data Kualitatif. Universitas Indonesia (UI- Perss).

11. Mislevy, R.J Wilson, M. (1992). Marginal Maximum Likelihood Estimation for a Psychometric Model of Discontinuous Development (Educational Testing Service Research Rep. No. RR 92-74 ONR). Princenton, NJ: Educational Testing Service.

12. Trianto. 2007. Mode Pembelajaran Terpadu Dalam Teori Dan Praktik. Jakarta: prestasi pustakaraya.

13. NasruddinAR. (2013). Strategi/metode Guru Dalam Mengontrol Siswa Yang Bertingkah Laku Menyimpang. Jurnal. Di akses pada tanggal 02 Mei 2017.

14. Reeves, Jacob M., "An In-Silico Assessment of Stemless Shoulder Arthroplasty: from CT to Predicted Bone Response" (2018). Electronic Thesis and Dissertation Repository. 5398. https://ir.lib.uwo.ca/etd/5398.

15. Webb, N., and Romberg, T. (1992), "Implications of the NCTM Standards for Mathematics Assessment," in Mathematics Assessment and Evaluation: Imperatives for Mathematics Education, ed. T. Romberg, Albany: State University of New York Press, pp. 37-60. [Google Scholar].

16. Wilson. M/ (1991). Measurement Models for New Forms of Student Assessment in the Mathematical Science, Australian Council for Educational Research, Geelong, Australia.

\section{AUTHOR PROFILE}

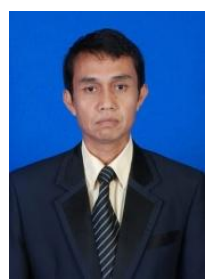

Irwan, I am a lecturer in Institut Seni Indonesia Padangpanjang. Bachelor Program in Sendratasik Major in Padang State University at 2000. Graduate Program in Educational Technology Major in Padang State University at 2007. Educational Doctoral in Padang State University at 2015. I am active in several shows in several countries in Southeast Asia such as Malaysia , Singapore and Thailand. I am also active in several iconic performances in Indonesia such as the jazz festival, Sawahlunto Jazz Festival. I am also often invited to be a jury at FLS2N for high school level in West Sumatra Province for the category of Music Creation since 2014 until now. Besides that, I also have a music studio as well as an instructor in that studio.

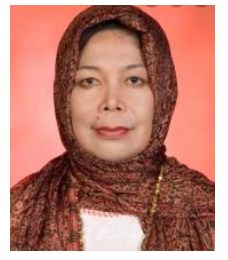

Agusti Efi Marthala

Name : : Agusti Efi.

Tittle : Professor

Departement: Departemen Science of Arts, Design and Science of craft art,

Facutly: Tourism and Hospitality Faculty of Padang State University

Expert : Sciences of Art \& Letter / Other artistical

specialities

Papers:

1. The clothes of Penghulu and Bundo kanduang

2. Minangkabau Batik with technical touches, decorative styles and philosophies

3. Systems, Symbols and Values in the Marriage Customs of the Minagkabau Community (Continued)

4. Inventory of Minangkabau Embroidery and Its Innovations in Home Industry (continued / year II)

5. Innovative Batik with Minangkabau Ornament Variety in Home Industry

6. Traditions and Changes in Minangkabau Wedding Clothes in the City of Padang

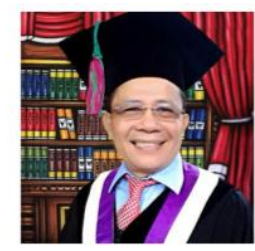

Atmazaki , $\mathrm{He}$ is a profesor at Indonesian Language Learning at Indonesian Language Education Program, Language and Art Faculty in Padang State University since 1994. Bachelor program of Indonesia Language Educational in IKIP Padang at 1983. Magister Program of Indonesian Language Program in IKP Bandung at 1992. At 2004 has graduated Language Eduacational Doctoral Program in Jakarta State University. Specifick research in assesment, material, methodology in Indonesian Language Learning. He has be presenter in some title such as DevelopingContextBasedReadingMaterial, Authentic Assessment inLanguageTeaching, TheUseofAuthentic TeachingMaterials BasedonLocal, TeachingIndonesian Language forForeigner:The Infulence of CultureandLocal Languages, TheImplementationofK-13inIndonesian language. Subjek: Mindset, Scientific Approach,Genre, dan Assessment.

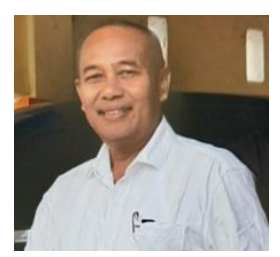

Syafri Anwar, I am a profesor inthe field of educational evaluation and assesment in learning process who works as a lecturer in the Social Science Faculty of Padang State University. I completed my doctoral at the Graduate Faculty of the Jakarta State University in 2005. My research concentration in addition to the evaluation and assesment about teachers and students, standardization of assesment instruments, is also a lot about evaliating school readiness to face disasters, especially in areas of West Sumatera. Some article on five last year with the title are Evaluation of institutional roles in realizing sustainable disaster preparedness programs, Development of a Geographic Curriculum based on the Love of the Homeland Character, Development of Thesis Assessment Instruments based on KKNI, Education Sustainability for communities in Post-Disaster areas, RTRT Evaluation and Development Activities in Padang City Based on Public Perception.

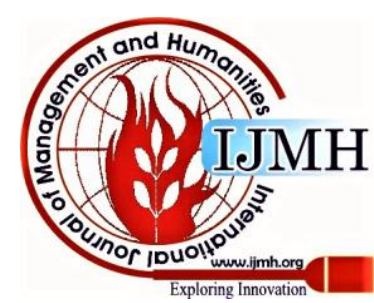

